\title{
The Economics of International Transfers
}

Steven Brakman and

Charles van Marrewijk 
PUBLISHED BY THE PRESS SYNDICATE OF THE UNIVERSITY OF CAMBRIDGE The Pitt Building, Trumpington Street, Cambridge CB2 1RP, United Kingdom

CAMBRIDGE UNIVERSITY PRESS

The Edinburgh Building, Cambridge, CB2 2RU, UK

http: //www.cup.cam.ac.uk

40 West 20th Street, New York, NY 10011-4211, USA http://www.cup.org

10 Stamford Road, Oakleigh, Melbourne 3166, Australia

(C) Cambridge University Press 1998

This book is in copyright. Subject to statutory exception and to the provisions of relevant collective licensing agreements, no reproduction of any part may take place without the written permission of Cambridge University Press.

First published 1998

Printed in the United Kingdom at the University Press, Cambridge

Typeset in Times 10/12pt [CE]

A catalogue record for this book is available from the British Library

Library of Congress Cataloguing in Publication data

Brakman, Steven.

The economics of international transfers / Steven Brakman and

Charles van Marrewijk.

p. $\mathrm{cm}$.

Includes bibliographical references (p. ).

ISBN $0521572142 \mathrm{hb}$

1. Balance of payments. I. Marrewijk, Charles van. II. Title.

HG3882.B72 1998

$382^{\prime} .17-$ dc $21 \quad 98-3809$ CIP

ISBN 0521572142 hardback 


\section{Contents}

List of figures page vi

List of tables vii

Preface ix

1 General overview and stylized facts 1

2 The Keynes-Ohlin controversy 22

3 Welfare effects: Samuelson's theorem 32

4 Generalizations of Samuelson's theorem $\quad 54$

5 Clouds on the horizon 1: distortions 71

6 Clouds on the horizon 2: third parties 96

7 The economics of multilateral transfers 119

8 The consequences of tied aid 133

9 Imperfect competition $\quad 152$

10 Dynamics, money and the balance of payments 174

$\begin{array}{lr}\text { Mathematical appendix } & 189\end{array}$

References $\quad 208$

Index 216 


\section{Figures}

2.1 Keynes and Ohlin compared

page 28

3.1 Leontief's example of a transfer paradox

3.2 Transfers and a change in numéraire

3.3 Market stability and the offer curve

6.1 Gale's example of a transfer paradox

8.1 Forced choice

9.1 Aid tied to food

162

9.2 Aid tied to manufactures in general 165

10.1 Neoclassical growth model 181

10.2 Neoclassical growth model and transfers 183

A.1 Special cases of the utility function 200 


\section{Tables}

1.1 Net unilateral transfers page 3

1.2 Britain's foreign trade 1796-1816, compared with unilateral foreign payments $\quad 7$

1.3 French foreign trade $1872-5$, compared with indemnity payments $\quad 12$

1.4 German reparations payments 1925-32 14

1.5 German foreign trade 1925-32, compared with reparations payments 14

1.6 Eastern Germany relative to western Germany, and

1.7 Historical examples of transfers 17

$\begin{array}{lll}1.8 & \text { Ten largest donors of net official development assistance } & 19\end{array}$

1.9 Total net development assistance from DAC countries, including multilateral organizations 20

1.10 Payments in the European Union $1996 \quad 21$

$\begin{array}{ll}2.1 & \text { Production and consumption patterns }\end{array}$

5.1 Sector-specific capital $\quad 82$

$\begin{array}{ll}5.2 & \text { Mobile capital } \\ 8.1 & 82\end{array}$

8.1 Tying of bilateral ODA by DAC members 134 


\section{General overview and stylized facts}

\subsection{What is a transfer?}

All economic exchanges involve transfers. In fast food restaurants, for instance, you will exchange cash for a hamburger. This is a bilateral transfer. It is bilateral because most fast food chains do not give hamburgers for free, nor are you willing to give up hard-earned dollars without being able to bite into a burger. The large majority of economic transfers are bilateral. Nowadays, it is usually goods or services for money, be it dollars, guilders, pounds or yen, or barter trade. This book is not about such transfers.

This is a book about unilateral transfers. It involves money sent to alleviate some of the distress after earthquakes or famines, or money sent to help a friend or relative, etc. In these instances the donating party helps the recipient without getting anything in return, save perhaps the good feeling of helping someone. For that reason it is called unilateral, because you get nothing in exchange for your dollars. Of course, one might also be on the receiving side of a transfer, for example if the state helps you to pay for university, or if you "enjoy" unemployment benefits. It is easy, but admittedly rather boring, to come up with an endless list of examples of unilateral transfers.

We analyze the economic consequences of international unilateral transfers. Why did we not state this more explicitly in the title of our book? Force of habit. For many years prominent economists have discussed "the transfer problem" with reference to international unilateral transfers (Eichengreen 1992). ${ }^{1}$ The former is, of course, a more succinct term with a better ring to it than the latter.

${ }^{1}$ Although we will discuss transfers in an international context, the methodology developed can easily be applied to all types of unilateral transfers, such as between economic agents within a single country. 


\subsection{Definitions}

We analyze international unilateral transfers. In principle all such transfers should be recorded in the balance-of-payments statistics. This is by no means straightforward, because the balance-of-payment statistics are based on a bookkeeping system, which requires that an offsetting entry should follow each transaction. ${ }^{2}$ In the case of unilateral transfers no offsetting transaction exists. However, the International Monetary Fund (IMF) requires that the balance of payments shows all economic values, including those without a quid pro quo, provided by residents of one country to residents of another country. The IMF publishes on a regular basis data on the balance of payments and makes a distinction between capital and current transfers.

Capital transfers consist of the transfer of ownership of a fixed asset or the forgiveness of a liability by a creditor when no counterpart is received in return. Furthermore, a transfer of cash is a capital transfer if it is linked to, or conditional on, the acquisition or disposal of a fixed asset (for example, an investment grant). A capital transfer should result in a commensurate change in the stock of assets of one or both parties in the transaction. Capital transfers can further be separated into those by the official sector and those by the private sector.

An example of a capital transfer by a government is debt forgiveness. When a government creditor in one country agrees with a debtor in another country to forgive all, or part, of the obligations of the debtor to that creditor, the amount forgiven is the capital transfer. Other capital transfers include investment grants, to finance all or part of the costs of acquiring fixed assets. In this case the recipients are obliged to use investment grants for purposes of (gross) fixed capital formation and are in this sense tied to specific investment projects. Investment grants in kind consist of transfers of transport equipment or machinery, or the direct provision of buildings or other structures such as docks, roads, airfields, hospitals, etc. Taxes are also included, for example inheritance taxes and gift taxes, and also compensation payments for damages such as oil spills and explosions. Examples of capital transfers by those not in the government sector are migrant transfers and debt forgiveness by such people or organizations. In principle, the items distinguished for the government sector can also be distinguished for other sectors.

Current transfers are, not surprisingly, all transfers that are not capital transfers. They directly influence the level of disposable income and

2 This section is based on the fifth edition of the balance-of-payments manual (International Monetary Fund, 1996). 
Table 1.1. Net unilateral transfers (\$ billions)

\begin{tabular}{lccccc}
\hline \hline & \multicolumn{1}{l}{1989} & & \multirow{2}{*}{1994} & \\
\cline { 2 - 3 } & Current & Capital & & Current & Capital \\
\hline Australia & 0.0 & 1.9 & -0.4 & 0.6 \\
Canada & -0.8 & 1.1 & -0.3 & 1.0 \\
France & -7.6 & -1.0 & & -8.3 & -4.8 \\
Germany & -16.7 & 0.1 & -37.9 & 0.7 \\
Italy & -3.5 & 0.9 & & -7.1 & 1.3 \\
Japan & -4.3 & n.a. & -7.5 & n.a. \\
Netherlands & -1.9 & -0.3 & & -5.3 & -0.9 \\
Sweden & -1.8 & -0.3 & & -1.8 & -0.1 \\
United Kingdom & -7.5 & n.a. & -8.2 & n.a. \\
United States & -26.3 & 0.2 & -35.2 & -0.6 \\
\hline \hline
\end{tabular}

Note: Net transfers are credit minus debit transfers.

Source: International Monetary Fund, Balance of Payments Statistics Yearbook, various issues.

influence the consumption of goods and services. As in the case of capital transfers a distinction between government and non-government transfers can be made. Government transfers, in cash or in kind, comprise transfers to finance current expenditures of the receiving government, gifts of food, clothing or medical supplies, gifts of military equipment, the contributions by governments to international organizations or by international organizations to governments, and also fines, penalties and interest on late payment of taxes. Basically the same examples can be given for nongovernment transfers. Remittances by migrants are also important.

Table 1.1 gives an indication of the size of the different kinds of transfers, as derived from the balance-of-payment statistics. The outflow of unilateral transfers is particularly large in Germany and the United States. Moreover, unilateral capital transfers tend to be smaller than unilateral current transfers.

\subsection{An early example of transfers: Alexander the Great}

Although transfers are now regular transactions and routinely described in the balance-of-payments statistics, the first sizable "international" transfers were most likely of an involuntary nature, dating far back in history. After losing a war or a battle, a country, region, city or tribe was likely to be forced to pay reparations or be plundered on the spot. That is how it used to be, and in many cases that is how it still is. We will 
encounter more examples of reparations payments in the remainder of this chapter, but we will begin with a particularly successful and vivid example: Alexander the Great. Alexander financed his war efforts by taking gold and silver and goods in kind from the many conquered peoples. He gave this to his soldiers directly, or after converting the bullion to coins. ${ }^{3}$ Bosworth (1993, pp. 241-2) summarizes this as follows:

Alexander himself was not greatly concerned with the regular payments of tribute. He relied on periodical influxes of bullion to finance the expenses of his campaigns and drew prodigally upon the accumulated reserves he discovered at Sardes, Damascus, Susa and, above all, Persepolis. Ultimately no less than 180,000 talents were concentrated at Ecbatana, a truly colossal sum which freed him from any budgetary constraints.

To put this wealth in proper perspective, Hammond (1989) writes: "We may recall for comparison that the output of Philip's mines at Philippi alone had been 1,000 talents a year, regarded then as a huge sum" (p. 157). Or, to give some more perspective, when Alexander is campaigning in the east in $331 \mathrm{BC}$ he is accumulating enough reserves to stop a rebellion back home: "He sent to Antipater 3,000 talents, a large sum, with which to buy support and mercenaries" (p. 160). Apparently, this was enough: "Antipater won the ensuing battle near Megalopolis, in which Agis and 5,300 of his army were killed, and obtained the capitulation of the enemy, Sparta providing hostages" (p. 160).

\subsection{Transfers and the balance of payments}

The history of transfers is long and varied. As the previous section illustrates, early examples were often concerned with battles and wars. These transactions are interesting from an historical point of view but do not contribute much to the understanding of the economic consequences of transfers. The first examples of economic analyses with respect to transfers deal with balance-of-payments problems. In the so-called classical theory of balance-of-payments adjustments, transfers are important because a current account disequilibrium can be seen as a unilateral transfer within a single period, that is a current account surplus or deficit which has to be settled in a future period; see also sections 10.2 and 10.3. The classical theory assumed that capital was more or less immobile and the adjustment had to come from changes in exports and imports accompanied by changes of the terms of trade and movements along given demand and supply curves. Although the language of the classical

${ }^{3}$ Of course, part of the gold and silver given to the soldiers may have been spent in the country of origin, but it was always a transfer between individuals of different nations. 
writers can sometimes be confusing to a present day reader the theory can be summed up as follows. Suppose a country has a current account surplus and there is a strict relation between gold reserves and the stock of money. Assuming that the quantity theory of money holds, this surplus causes an increase in prices and therefore reduces the demand for exports; see also Wicksell (1918). ${ }^{4}$ In the deficit country the opposite happens. The adjustment of prices gradually eliminates the surplus and the deficit. This theory of balance-of-payments adjustments can easily be stated in terms which are found in the transfer literature and thus gives one of the first theoretical analyses of the transfer problem. The first and most complete statement of this theory is often associated with the name of David Hume.

\subsubsection{David Hume}

The mechanism equilibrating the balance of payments in the gold exchange standard under normal circumstances originates from the Scottish economist David Hume. His objective was to demonstrate the automatic nature of this so-called price-specie-flow mechanism, that is it did not require the "benefit" of (mercantilist) government intervention (Hume 1985 [1752]): ${ }^{5}$

Suppose four-fifths of all the money in Great Britain to be annihilated in one night, and the nation reduced to the same condition, with regard to specie, as in the reigns of the Harrys and the Edwards, what would be the consequence? Must not the price of all labor and commodities sink in proportion, and everything be sold as cheap as they were in those ages? What nation could then dispute with us in any foreign market, or pretend to navigate or to sell manufactures at the same price, which to us would afford sufficient profit? In how little time, therefore, must this bring back the money which we had lost, and raise us to the level of all the neighboring nations? Where, after we have arrived, we immediately lose the advantage of the cheapness of labor and commodities; and the farther flowing in of money is stopped by our fullness and repletion.

Again, suppose that all the money in Great Britain were multiplied fivefold in a night, must not the contrary effect follow? Must not all labor and commodities rise to such an exorbitant height, that no neighboring nations could afford to buy from us; while their commodities, on the other hand, became comparatively so

${ }^{4}$ Note the close resemblance of this theory to the monetary approach to the balance of payments, although in the monetary approach the adjustment also comes about by the direct influence of the stock of money on expenditure.

5 This chapter and the next will be exceptional in their rather frequent use of quotations. We have done so deliberately in this "historical" part to "let the authors speak for themselves." It is useful to keep in mind T. S. Eliot's words: "Someone said: 'The dead writers are remote from us because we know so much more than they did.' Precisely, and they are that which we know." 
cheap, that, in spite of all the laws which could be formed, they would run in upon us, and our money flow out; till we fall to a level with foreigners, and lose that great superiority of riches which had laid us under such disadvantages?

Changes in relative prices and their influence on the volume of exports and imports are therefore, according to Hume, the chief driving force behind equilibrating the balance of trade. In addition, and to a limited extent, exchange rate changes within the limits of the gold points serve the same purpose. Thus, according to the price-specie-flow mechanism a unilateral transfer should reduce prices to produce an export surplus. The main purpose of Hume was, however, not to develop a theory of transfers, but to react to what he considered to be gross errors by contemporary writers; that is, the mercantilists. His goal was to show that the mercantilists were wrong when they stated that if England ran a balance-of-payments deficit (or current account deficit) the outflow of gold would drain the entire gold reserves of the country.

\subsubsection{Adam Smith}

War has been a frequent motivation for transfer payments and it was also the driving force behind the discussion of a transfer problem by the Scottish economist Adam Smith. In this particular instance it was not for reparations payments or indemnities, but for subsidies to Great Britain's allies against France in the Seven Years War (1756-63). Smith (1981 [1776], pp. 441-2) first gives information on the enormous size of the transfer:

The last French war cost Great Britain upwards of ninety millions ... More than two-thirds of this expense was laid out in distant countries; in Germany, Portugal, America, in the ports of the Mediterranean, in the East and West Indies ... Let us suppose, therefore, according to the most exaggerated computation which I remember to have either seen or heard of, that, gold and silver together, it [the circulating gold and silver in Great Britain] amounted to thirty millions. Had the war been carried on, by means of our money, the whole of it must, even according to this computation, have been sent out and returned again at least twice, in a period between six and seven years.

Smith concludes that such a rapid circulation of money was impossible so that payments must have been made in terms of commodities. For this he gives the following explanation (Smith 1981 [1776], p. 443):

The transportation of commodities, when properly suited to the market, is always attended with a considerable profit; whereas that of gold and silver is scarce ever attended with any. When those metals are sent abroad in order to purchase foreign commodities, the merchant's profit arises, not from the purchase, but from the sale of the returns. But when they are sent abroad merely to pay a debt, 
Table 1.2. Britain's foreign trade 1796-1816, compared with unilateral foreign payments (annual averages in £ millions)

\begin{tabular}{llcc}
\hline \hline & $1793-1805$ & $1796-1805$ & $1806-16$ \\
\hline Exports & n.a. & 47.3 & 54.5 \\
Imports & n.a. & 53.2 & 63.0 \\
Trade volume & n.a. & 100.6 & 117.5 \\
Foreign payments & 3.0 & 2.3 & 10.9 \\
Payments/exports & $6.4 \%{ }^{a}$ & $4.9 \%$ & $20.1 \%$ \\
Payments/imports & $5.7 \%{ }^{a}$ & $4.4 \%$ & $17.4 \%$ \\
Payments/trade volume & $3 . \%^{a}$ & $2.3 \%$ & $9.3 \%$ \\
\hline \hline
\end{tabular}

Note: ${ }^{a}$ Calculated with reference to trade in 1796-1805.

Source: Machlup 1966.

he gets no returns, and consequently no profit. He naturally, therefore, exerts his invention to find out a way of paying his foreign debts, rather by the exportation of commodities than by that of gold and silver.

This explanation of balance-of-payments adjustment is remarkable in that the higher profitability of sending goods rather than specie is inconsistent with Smith's own doctrine of the equality of profit in the employment of different capitals.

\subsubsection{The bullionist controversy}

The famous bullionist controversy started with the large payments of Great Britain to continental Europe during the Napoleonic wars. Detailed information on Great Britain's balance of payments is lacking, but it seems that these transfers were large relative to exports, but rather small relative to GDP. With respect to the transfer problem (see chapter 2) it is interesting to note that during the period in which the largest payments were made, 1806-16, Britain's terms of trade deteriorated by about 30 percent (Imlah 1958). This debate was one of the first in which large payments to "over-sea countries" gave rise to economic analyses of the issues involved.

On February 27, 1797, Great Britain's war with France had brought a suspension of gold payments by the Bank of England, which was now authorized to refuse payments for its notes in gold to save it from a state of chronic insolvency. Subsequent renewals prolonged the restriction until 1821. At this time Great Britain was involved in heavy remittances to its allies (see tables 1.2 and 1.7), and the government was involved in 
large-scale borrowing. Simultaneously, a remarkable series of bad harvests led to large-scale imports of wheat and disturbed the balance of payments. Inconvertibility combined with rising prices resulted in a premium for gold in the market over the quoted mint price. With convertible paper this obviously cannot occur because then the exchange rate between two currencies is determined by the ratio of the gold prices plus or minus the cost of shipping and handling gold.

The "bullionists," among them the English economists Henry Thornton, David Ricardo and John Wheatley, advocated resumption of specie payments by the Bank of England at the earliest possible date. In general the "excessive" issue of irredeemable bank-notes was considered to be responsible for the evil of inflation, although Thornton's analysis following the Hume type of explanation was considerably more cautious in listing the many causes, consequences and symptoms of inflation. Thornton investigated, in particular, a crop failure which necessitated increased imports of grain and arrived at a shift in the terms of trade against the paying country. As will become clear in due course, a crop failure can be analyzed in terms of transfers; see chapter 5. Ricardo (1810) denied that a crop failure or subsidy would disturb the balance of payments at all and questioned any need for a mechanism of adjustment with the peculiar reasoning that it would be a waste of effort to first send specie abroad only to have it returned at a later time:

The ultimate result then of all this exportation and importation of money, is that one country will have imported one commodity in exchange for another, and the coin and bullion will in both countries have regained their natural level. Is it to be contended that these results would not be foreseen, and the expense and trouble attending these needless operations effectually prevented, in a country where capital is abundant, where every possible economy in trade is practiced, and where competition is pushed to its utmost limits? Is it conceivable that money should be sent abroad for the purpose merely of rendering it dear in this country and cheap in another, and by such means to insure its return to us?

There is no need to comment on the implied omniscience and capabilities of individual agents in abstaining from sending money abroad because it will ultimately return to the country of origin. Suffice it to say that many years later some authors give Ricardo more credit than he probably deserves for claiming that a relative price change is not necessary. As Blaug (1978, p. 219) puts it:

Oddly enough Ricardo's argument is correct if we assume that he was thinking of the modern Keynesian theory of transfer payments and assumed it to be operative immediately. In other words, if a failure of harvest would immediately and automatically bring about a proportionate change in reciprocal demands of countries for each other's products, no alteration whatever would take place in 
the exchanges. On this ground some authors have credited Ricardo with extraordinary prescience ... The whole argument is somewhat forced, and Ricardo would hardly have adopted it had he not been so anxious to attribute the entire "premium on bullion" to an excessive issue of Bank Notes. To improve his presentation by crediting him with a Keynesian theory of transfers seems to miss the point.

Schumpeter (1954, p. 704, n. 13) and Silberling (1924) give similar views. The latter is also useful for a more detailed account of the bullion controversy.

Wheatley (1807) deserves perhaps more credit in this respect for pointing out income effects in addition to price effects by maintaining that crop failures or subsidies would alter the relative demands of two countries and their ability to purchase each other's goods:

If, then, it be correct in theory, that the exports and imports to and from independent states have a reciprocal action on each other, and that the extent of the one is necessarily limited by the extent of the other, it is obvious, that if no demand had subsisted in this country from 1793 to 1797 for corn and naval stores, the countries that furnished the supply would have possessed so much less means of expending on our exports, as an inability to sell would of course have created an equal inability to buy. It is totally irregular, therefore, to infer, that our exports would have amounted to the same sum, had the import of the corn and naval stores been withheld, as those who provided the supply would have been utterly incapable of purchasing them.

In the discussion several elements can be recognized which will later also dominate other debates involving transfers: the influence of transfers on the balance of payments; whether or not balance-of-payments disequilibria would give rise to terms-of-trade changes; and how this could come about. In the bullionist controversy the inconvertibility of paper money for gold resulted in a rise in the price of gold relative to its mint price; the implied depreciation of paper money meant a terms-of-trade depreciation (see, for a related discussion, Taussig [1917, 1918] and Hollander [1918]). As we will see in chapter 2, this debate resembles the famous Keynes-Ohlin debate on the consequences of transfers; both debates failed to put the transfer problem in a general equilibrium context.

\subsubsection{John Stuart Mill}

The English economist John Stuart Mill, in his authoritative Principles, attributes to relative price changes almost sole responsibility for restoring equilibrium in the balance of payments. Only on one occasion does Mill mention a relative shift of income as an equilibrating force; on both 
points, see Viner $(1955$, p. 300). Thus, the conventional wisdom in those days that a transfer of funds from one country to another will worsen the paying country's terms of trade, thereby creating a secondary burden is argued by Mill (1848, book III, ch. XXI, para. 4) as follows (our emphasis): 6

The supposed annual remittances being made in commodities, and being exports for which there is to be no return, it is no longer requisite that the imports and exports should pay for one another: on the contrary, there must be an annual excess of exports over imports, equal to the value of the remittance. If, before the country became liable to the annual payment, foreign commerce was in its natural state of equilibrium, it will now be necessary, for the purpose of effecting the remittance, that foreign countries should be induced to take a greater quantity of exports than before: which can only be done by offering those exports on cheaper terms, or, in other words, by paying dearer for foreign commodities. The international values will so adjust themselves that, either by greater exports, or smaller imports, or both, the requisite excess on the side of exports will be brought about; and this excess will become the permanent state. The result is that a country which makes regular payments to foreign countries, besides losing what it pays, loses also something more, by the less advantageous terms on which it is forced to exchange its productions for foreign commodities.

The idea that a country which makes a transfer abroad suffers a secondary burden because of a deterioration of its terms of trade (that is, the classical theory of transfers) was termed the "orthodox" view by Ohlin (1928a).

\subsubsection{Charles Bastable's critique}

At first glance, and partly as a result of its eloquent wording, Mill's argument in the previous subsection may sound convincing. The main weakness in the analysis was pointed out most explicitly for the first time by Charles Bastable in 1889. After discussing a few examples, in one of which the two countries engaged in the transfer are not involved in any trade such that there cannot be a secondary burden, Bastable cuts to the heart of the matter (1889, p. 15):

He [Mill] has, however, omitted an important qualification. B [the recipient], having got 100,000 quarters without cost, is the better able to purchase: her sum of income is higher. It is therefore possible that she may desire to take a greater quantity, - say 200,000 quarters, purchasing 100,000. This increased demand would affect the terms of trade to her [the recipient's] disadvantage, and would so far counteract the loss incurred by A [the donor].

${ }^{6}$ The argument here is for the case of barter trade. Mill goes on to argue that there is no difference if money is introduced or transferred instead. 
In short, the recipient's income is higher as a result of the transfer. This increases the recipient's demand for goods in general and for the donor's export goods in particular, which in turn potentially improves the donor's terms of trade and facilitates the required generation of an export surplus for the donor.

The conclusion of the debates discussed in this section is that from early on it has been recognized that balance-of-payments disequilibria or transfers lead to terms-of-trade effects and quantity adjustments. The primary attention in the discussion is on terms-of-trade effects, rather than on quantity adjustments. The subsequent literature did not add much to our understanding of the transfer problem, and we had to wait until 1929 for a renewed interest in and more systematic treatment of the problem. This is discussed in the next chapter.

\subsection{German transfer problems}

France and Germany were the main participants in two well-known warrelated international transfer schemes that attracted a lot of analytical and political attention. The first scheme involved a transfer payment from France to Germany after the war in 1870-1. The second scheme involved a transfer payment from Germany to France (and other allied forces) after World War I, some fifty years later.

\subsubsection{Franco-German indemnity of 1871}

Taussig (1927) notes that the frequent reference in his days to the ease with which France fulfilled its indemnity obligations after the FrancoPrussian War of 1870 is quite misleading owing to the exceptional circumstances of this case. ${ }^{7}$ France was required to pay 4,976 million francs ( 5 billion in indemnity, plus 301 million in interest on postponed payments, minus 325 million for the railroads of Alsace-Lorraine, which were taken over by the German Empire and whose owners were reimbursed by France). Unlike most cases (the Chinese Boxer indemnities of 1901, the Turkish indemnity of 1878 or Germany after World War I) the period for the arrangement of the transfer was so short that it was almost like a lump sum being handed over at once, and this appeared to impose a formidable burden on France in relative terms; see table 1.3. The first task of financing was astoundingly successful; France floated two great loans ( 1.5 billion in 1871 and 3 billion in 1872), the latter being oversubscribed more than tenfold. The French bonds were purchased to

\footnotetext{
7 This subsection is based on chapter 22 of Taussig (1927).
} 
The economics of international transfers

Table 1.3. French foreign trade 1872-5, compared with indemnity payments (annual averages in million francs)

\begin{tabular}{lc}
\hline \hline Exports & 4,159 \\
Imports & 3,649 \\
Trade volume & 7,808 \\
Indemnity (one-fourth) & 1,248 \\
Indemnity/exports & $30.0 \%$ \\
Indemnity/imports & $34.2 \%$ \\
Indemnity/trade volume & $16.0 \%$ \\
\hline \hline
\end{tabular}

Source: Machlup 1966.

a large extent by foreigners and by French investors who disposed of their foreign investments. The second task of transferring the funds to Germany, mainly in the form of bills of exchange, was equally successful. Taussig (1927, p. 266) attributes this to a reduction in French foreign investments:

The one adequate resource was the great mass of accumulated French investments in foreign countries. These investments existed chiefly in the form of foreign securities held by Frenchmen. It was their sale that supplied most of the funds for the great loans and for the bills of exchange, the funds both for the domestic and foreign tasks.

Taussig (1927, p. 268) concludes: "What happened under these circumstances (so fortunate for France) gives hardly any clue to what might happen under such conditions as would ordinarily have to be faced by a country required to pay a great lump-sum indemnity ... The French experience helps hardly at all for the purposes of verification."

\subsubsection{German payments after World War I}

Germany was obliged by the Treaty of Versailles in 1919 to pay reparations to the victorious nations after World War I. ${ }^{8}$ However, the Allied nations could not agree on a total reparations sum at the Paris Peace Conference in 1919. As a practical solution to the resulting stalemate situation they asked the Germans to suggest a proposal for a settlement. The Allied nations hoped this procedure would lead to a speedy solution. Germany, quite understandably, tried to strike as hard a bargain as possible. A number of conferences were held to solve the

\footnotetext{
${ }^{8}$ This subsection is based on chapter 15 of Machlup (1966).
} 
problem of calculating the total sum of the reparations. The climax of these conferences was reached in 1921 in London. Germany made an offer the Allied nations had to refuse and after an ultimatum this situation led to the occupation of three towns in the Ruhr. In April 1921 the Reparations Commission finally came up with a total figure. They recommended a total liability of 132 billion marks (6,600 million pounds) payable in annual installments of 2 billion marks (100 million pounds). This annual figure amounted to about 25 percent of German exports at the time, and also meant that the last installment had to be paid in 1988! Hesitantly, the Germans began paying their debt. This did not imply that they agreed to the huge reparations. On the contrary, the prime minister (Joseph Wirth) and the minister of reconstruction (Walter Rathenau) hoped that by attempting to pay the annual installments they could show their economic impossibility. At first Germany tried to pay the installments by borrowing on the international capital market, which led to a sharp fall of the mark in the exchange markets. Repeatedly the Germans asked for moratoria. Again the Allied nations could not agree and in 1923 French and Belgian troops entered the Ruhr in order to secure "productive guarantees." Germany stopped all payments and broke off all diplomatic relations. Workers went on strike in the Ruhr and the burden of paying wages to those on strike proved too formidable for the German economy; a period of hyperinflation started. At the beginning of 1923 a dollar was worth about 18,000 marks. In November, 4 billion marks had to be paid for a dollar! A detailed account of how all this helped to pave the way for Hitler can be found in Carr (1987).

Before 1924 payments were chiefly in kind (materials and equipment). These were, not surprisingly, appraised at low values by the recipients and at high values by Germany. The Dawes Plan of 1924 scheduled annual payments of increasing magnitude. After five years, the payments would also depend on an index measuring Germany's prosperity. This was revised in 1929 under the Young Plan. In response to the world depression of 1929 and dwindling world trade, actual payments were suspended in 1931 and officially stopped in June 1932. Table 1.4 presents payments statistics from 1925 to 1932.

In the early years, from 1925 to 1927, large amounts of foreign (mainly American) loans were received by Germany. The excess of these loans over the reparations payments could be used to incur import surpluses. After 1929, until the Hoover moratorium of 1931, reparations payments exceeded capital imports. In relative terms the demands imposed on the German economy do not seem exceptional. Indeed, if we compare the payments relative to either exports, imports or the trade volume in tables $1.2,1.3$ and 1.5 of Britain in 1796-1816, France in 1872-5 and Germany 
Table 1.4. German reparations payments 1925-32 (million Reichsmarks)

\begin{tabular}{llllr}
\hline \hline & $\begin{array}{l}\text { Payments in RM } \\
\text { for deliveries in } \\
\text { kind }\end{array}$ & $\begin{array}{l}\text { Payments in RM } \\
\text { for armies of } \\
\text { occupation }\end{array}$ & $\begin{array}{l}\text { Payments in } \\
\text { foreign } \\
\text { currencies }\end{array}$ & Total \\
\hline $1924-5$ & 414 & 208 & 271 & 893 \\
$1925-6$ & 658 & 102 & 416 & 1,176 \\
$1926-7$ & 617 & 82 & 683 & 1,382 \\
$1927-8$ & 725 & 71 & 943 & 1,739 \\
$1928-9$ & 985 & 49 & 1,419 & 2,453 \\
$1929-30$ & 515 & 32 & 728 & 1,275 \\
$1930-1$ & & & 921 & 1,385 \\
$1931-2$ & & & 747 & 961 \\
Total & & & & 11,264 \\
\hline \hline
\end{tabular}

Note: Data are for "annuity years" ending July 31.

Source: Machlup 1966.

Table 1.5. German foreign trade 1925-32, compared with reparations payments (annual averages in million Reichsmarks)

\begin{tabular}{lcc}
\hline \hline & $1925-8$ & $1929-32$ \\
\hline Exports & 10,840 & 10,214 \\
Imports & 12,224 & 8,808 \\
Trade volume & 23,064 & 19,022 \\
Trade balance & $-1,384$ & 1,406 \\
Reparations payments & 1,182 & 1,498 \\
Reparations/exports & $10.9 \%$ & $14.7 \%$ \\
Reparations/imports & $9.7 \%$ & $17.0 \%$ \\
Reparations/trade volume & $5.1 \%$ & $7.9 \%$ \\
\hline \hline
\end{tabular}

Note: Trade data are for calendar years. Reparations data are for "annuity years" ending on July 31 in the corresponding calendar year.

Source: Machlup 1966.

in 1925-32 the German payments show a relatively modest ratio. Machlup (1966, p. 385) even remarks: "It is hard to understand why some economists in the late 1920's made such a fuss about the supposed severity of the German transfer problem." This is, we think, a quite unfair criticism which does not take into consideration the exceptional circumstances of France in 1871 (see subsection 1.5.1), the dismal 
circumstances of Germany after the world depression in 1929 or the simple fact that under the Young Plan, German reparations payments were scheduled to continue until 1988.

\subsubsection{Current German transfer problems}

In the last decade of this century Germany is again involved in a substantial unilateral transfer payment. Depending on one's perspective this is either a national or an international transfer, since we are referring to the payments from western Germany to eastern Germany after the German unification following the destruction of the Berlin Wall. On July 1, 1990, some three months before the official reunification on October 3, 1990, the D-mark was introduced in the German Democratic Republic (the former East Germany) and this initiated the process of economic unification.

While eastern Germany had a population of about 26 percent of that of western Germany, its output was only 8 percent of the latter's in 1991 (Welfens 1992). The costs to both western and eastern Germany of the unification were initially seriously underestimated (Welfens 1992, p. 174). The transfers from west to east are large by any standard. Almost immediately from the start of the unification it became clear to the German government that the infrastructure, the communication system, the sewerage system and the maintenance of buildings in general needed a complete overhaul. It is estimated that the net transfers to the eastern part of Germany amount to 4.25 percent of the GDP of western Germany on an annual basis. From 1991 to 1995 almost DM 900 billion were transferred from the western to the eastern part. ${ }^{9}$ At the date of political unification, October 3, 1990, it was widely expected that closing the east-west income gap in Germany would take less than a decade, because of the massive transfers. But at present, the expected time-frame for closing the intra-German income gap is several decades rather than one, because the initial gap between eastern and western Germany turned out to be much larger than had been expected; see Brakman and Garretsen (1994).

The transfers from western Germany to the new Länder were quite substantial from a western German perspective. Most of this was used to support investment and develop the infrastructure. For eastern Germany these transfers were truly enormous, namely some 70 percent of national income in 1991, leveling off to about 50 percent in 1994 (Association of German Economic Research Institutes 1991-5). Nonetheless, the costs of

${ }^{9}$ Deutsche Bundesbank, Monatsbericht, October 1996, p. 26. 
Table 1.6. Eastern Germany relative to western Germany (western Germany $=100)$ and transfers

\begin{tabular}{lcccccc}
\hline \hline & 1991 & 1992 & 1993 & 1994 & 1995 & 1996 \\
\hline $\begin{array}{l}\text { GDP per capita (1991 prices) } \\
\begin{array}{l}\text { Unemployment as percentage } \\
\text { of labor force }\end{array}\end{array}$ & 31.1 & 38.0 & 42.7 & 44.6 & 45.4 & 45.4 \\
$\begin{array}{l}\text { Unit wage cost } \\
\text { Transfers from West to East } \\
\quad(\text { billion DM) }\end{array}$ & 145.3 & 139.3 & 131.7 & 129.8 & 130.6 & 132.4 \\
\hline \hline
\end{tabular}

Source: Deutsche Bundesbank, Saisonsbereinigte Wirtschaftszahlen, statistisches Beiheft zum Monatsbericht, various issues.

unification were substantial for eastern Germany. After the collapse in 1990-1, resulting in high unemployment, a strong (relative) recovery started, but from 1994 the eastern German catching-up leveled off (see table 1.6). After the initial collapse, the eastern German economy as a whole performed well in the period 1991-4, certainly compared to western Germany. The size of the transfer was very large, especially for the recipients in the East. For example, each man, woman and child received about DM 15,000 in 1992. Undoubtedly, given the enormous transfers from western Germany for investment and infrastructure, the eastern German economy would have done much better if the East German mark had not been exchanged one-for-one for the West German mark (for details, see Welfens [1992]) and if there had not been a politically inspired decision forcefully to increase eastern German wages to the western German level within a certain time-frame. Both decisions resulted in very high relative unit wage costs. These two policy decisions, in conjunction with the transition process in eastern Germany itself, from a centrally planned economy to a market economy, make it extremely difficult to gauge the contribution of the transfer scheme to the economic and social well-being of eastern Germany.

\subsection{Evaluation of some historical transfers}

In the preceding sections we briefly discussed some of the well-known examples of war reparations. The most famous is, without doubt, the reparations payments following World War I, because it inspired Keynes to write his Economic Consequences of the Peace and led to the Keynes-Ohlin debate discussed in chapter 2. It would be a mistake to think that all the attention given to the German reparations implies that 
Table 1.7. Historical examples of transfers

\begin{tabular}{|c|c|c|c|c|}
\hline & Trade balance & Transfer $(\mathrm{T})$ & T/exports & T/GNP \\
\hline \multicolumn{5}{|c|}{ Great Britain } \\
\hline $1793-1805$ & n.a. & $£ 3.0 \mathrm{~m}$. & $6.4 \%$ & $1.0 \%$ \\
\hline $1796-1805$ & n.a. & $£ 2.3 \mathrm{~m}$. & $4.9 \%$ & n.a. \\
\hline $1806-16$ & n.a. & $£ 10.9 \mathrm{~m}$. & $20.1 \%$ & n.a \\
\hline \multicolumn{5}{|l|}{ France } \\
\hline $1867-71$ & $\mathrm{FF}-119 \mathrm{~m}$ & n.a. & n.a. & n.a. \\
\hline $1872-75$ & FF $510 \mathrm{~m}$ & FF $248 \mathrm{~m}$ & $30.0 \%$ & $5.6 \%$ \\
\hline \multicolumn{5}{|l|}{ Germany } \\
\hline $1925-28$ & $\mathrm{RM}-1,384 \mathrm{~m}$. & RM 1,182 m. & $10.9 \%$ & $2.5 \%{ }^{a}$ \\
\hline $1929-32$ & RM 1,406 m. & RM 1,498 m. & $14.7 \%$ & $2.5 \%{ }^{a}$ \\
\hline $1953-59$ & $\$ 914 \mathrm{~m}$ & $\$ 233 \mathrm{~m}$ & $2.0 \%$ & $0.6 \%$ \\
\hline $1959-65$ & $\$ 1,275 \mathrm{~m}$. & $\$ 573 \mathrm{~m}$. & $3.8 \%$ & $0.9 \%$ \\
\hline \multicolumn{5}{|c|}{ West to East Germany } \\
\hline $1991-95$ & n.a. & DM 900 b. & n.a. & $4.25 \%$ \\
\hline \multicolumn{5}{|l|}{ Finland } \\
\hline $1944-48$ & n.a & OM 7,832 m. & n.a. & $4.0 \%$ \\
\hline $1948-52$ & OM 17,200 m. & OM 10,446 m. & $8.7 \%$ & $2.2 \%$ \\
\hline \multicolumn{5}{|l|}{ Italy } \\
\hline $1947-56$ & $\$-682 \mathrm{~m}$ & $\$ 23 \mathrm{~m}$. & $0.015 \%$ & $0.002 \%$ \\
\hline $1956-65$ & $\$-1,078 \mathrm{~m}$. & $\$ 15 \mathrm{~m}$. & $0.004 \%$ & $0.001 \%$ \\
\hline \multicolumn{5}{|l|}{ Japan } \\
\hline $1955-60$ & $\$-559 \mathrm{~m}$ & $\$ 45 \mathrm{~m}$ & $1.5 \%$ & $0.002 \%$ \\
\hline 1960-65 & $\$-833 \mathrm{~m}$ & $\$ 63 \mathrm{~m}$. & $1.1 \%$ & $0.001 \%$ \\
\hline \multicolumn{5}{|c|}{ United States } \\
\hline $1950-55$ & $\$ 2.4 \mathrm{~b}$ & $\$ 4.4 \mathrm{~b}$ & $29.0 \%$ & $1.5 \%$ \\
\hline $1956-61$ & $\$ 4.4 \mathrm{~b}$. & $\$ 7.0 \mathrm{~b}$. & $31.1 \%$ & $1.8 \%$ \\
\hline $1962-67$ & $\$ 5.4 \mathrm{~b}$ & $\$ 8.1 \mathrm{~b}$. & $25.4 \%$ & $1.5 \%$ \\
\hline
\end{tabular}

Notes: The table shows averages over the respective periods. ${ }^{a} 1924-32$ average. Source: Stern 1973, p. 258; and Deutsche Bundesbank for West to East German transfers.

the actual payments were very large compared to the other examples described above. Table 1.7 gives some additional examples, and relates these to the size of the donor's exports and national income (see also Viner 1924).

The table shows four examples of relatively large payments in relation to exports and national income: (i) the reparations paid by France to Germany in the period 1872-5; (ii) the Finnish payments to the Soviet Union in 1944-8; (iii) the foreign transfers by the United States, which has since World War II made large payments, consisting mostly of 
military spending abroad and foreign aid; and (iv) the transfers from western to eastern Germany. Italy and Japan have made some reparations payments, but they have been relatively small compared to exports and national income. In retrospect, it seems that the attention the German reparations received after World War I can to a large extent be explained by the fact that it inspired Keynes and Ohlin to discuss the matter, rather than by the size of the transfer itself.

\subsection{From war reparations payments to foreign aid}

After World War II attention to transfers was no longer focused on reparations and balance-of-payments issues. The literature on balanceof-payments disequilibria shifted towards analyses with MundellFleming-type models and related exercises with exchange rate models. These models could easily analyze the consequences of transfers and the debate between Keynes and Ohlin could simply be resolved by applying these models to transfers (this also implies that most economists thought that Ohlin was right and Keynes was wrong, because in the MundellFleming-type models spending effects dominate the analyses). ${ }^{10}$ At the same time, war reparations as such were not different from transfers in general and were sufficiently small that a separate analysis seemed unnecessary. What became important was that, in the slipstream of the decolonization process, the former colonial powers felt an obligation to give development aid (see, for example, Abrams and Lewis [1993] and Ansari and Singer [1982]). One of the first major examples was the aid given by the United States as a result of the Economic Cooperation Act of 1948, better known as the Marshall Plan. The main aim of the United States was to help its allies with reconstructing their economies after World War II. Many European countries received aid; from 1948 to 1954 the United States donated a total of $\$ 15$ billion of which $\$ 13$ billion was in the form of gifts. The remainder consisted mainly of loans. The Marshall aid per capita averaged about $\$ 39$ for all recipients combined. ${ }^{11}$

The main objective of aid programs is to increase welfare in the developing world. The analysis therefore shifted from balance-of-payments issues to the welfare effects of transfers. This problem is also

${ }^{10}$ As will be made clear in the next chapter both types of reasoning, the classical and the Keynesian, are incomplete.

11 See De Nederlandse Bank (1954, p.158). In a private correspondence on this matter, Jan Pen argues that the official figures understate the importance of Marshall aid for the recipients. First, the aid was at official parity, while the market value of the dollar was much higher. Second, Europe was confronted with a solvency constraint which threatened to severely hamper its imports. This constraint was removed or alleviated by Marshall aid. 
Table 1.8. Ten largest donors of net official development assistance (\$ billions); percentage of GNP shown in parentheses

\begin{tabular}{lllllll}
\hline \hline & 1964 & 1974 & 1979 & 1984 & 1989 & \multicolumn{1}{l}{1994} \\
\hline Japan & $0.1(0.1)$ & $1.1(0.2)$ & $2.7(0.3)$ & $4.3(0.3)$ & $9.0(0.3)$ & $13.2(0.3)$ \\
United States & $3.6(0.6)$ & $3.4(0.2)$ & $4.7(0.2)$ & $8.7(0.2)$ & $7.7(0.2)$ & $9.9(0.2)$ \\
France & $0.8(0.9)$ & $1.6(0.6)$ & $3.4(0.6)$ & $3.8(0.8)$ & $5.8(0.8)$ & $8.5(0.6)$ \\
Germany & $0.5(0.4)$ & $1.4(0.4)$ & $3.4(0.5)$ & $2.8(0.5)$ & $4.9(0.4)$ & $6.8(0.3)$ \\
United Kingdom & $0.5(0.5)$ & $0.7(0.4)$ & $2.2(0.5)$ & $1.4(0.3)$ & $2.6(0.3)$ & $3.2(0.3)$ \\
Italy & $0.0(0.1)$ & $0.2(0.1)$ & $0.3(0.1)$ & $1.1(0.3)$ & $3.6(0.4)$ & $2.7(0.3)$ \\
Netherlands & $0.0(0.3)$ & $0.4(0.6)$ & $1.5(1.0)$ & $1.3(1.0)$ & $2.1(0.9)$ & $2.5(0.8)$ \\
Canada & $0.1(0.2)$ & $0.7(0.5)$ & $1.1(0.5)$ & $1.6(0.5)$ & $2.3(0.4)$ & $2.3(0.4)$ \\
Sweden & $0.0(0.2)$ & $0.4(0.7)$ & $1.0(1.0)$ & $0.7(0.8)$ & $1.8(1.0)$ & $1.8(1.0)$ \\
Australia & $0.1(0.5)$ & $0.4(0.6)$ & $0.6(0.5)$ & $0.8(0.5)$ & $1.0(0.4)$ & $1.1(0.4)$ \\
\hline \hline
\end{tabular}

Note: Figures also include donations to multilateral organizations.

Source: OECD, Development Assistance Committee, Development Co-operation, various issues.

central in this book. In table 1.8 we give some data on development aid in recent years for the ten largest donors.

This shows that the largest donors are to be found among the "old" industrial powers. Large countries contribute the most, but relatively small countries like the Netherlands, Sweden and Australia also belong among the largest donors. Over time, Japan has become the largest donor in absolute terms, rising from a share of $2 \%$ in 1964 to $25 \%$ in 1994. It took over the first place from the United States, which fell from a share of $62 \%$ in 1964 to $19 \%$ in 1994 . Comparing the data with United Nations Resolution No. 2626, which states that the developed countries should give at least $0.7 \%$ of GNP in development assistance, it follows that only the small donors comply with the resolution (also among these countries are Norway and Denmark). This promise was renewed by the European Union donors at the "Earth Summit +5 " Conference held in New York in 1997.

Table 1.9 shows receiving countries, aggregated into larger areas. This clearly demonstrates that the largest recipients are to be found among the poorest regions in the world. Africa South of the Sahara, for example, received roughly a third of official development assistance in 1994. This is, of course, to be expected. The same holds grosso modo within each region: the poorest nations within a region receive the largest sum of development aid. The two tables together suggest that the main purpose of transfers is to relieve the burden of poverty in the poorest regions in 
Table 1.9. Total net development assistance from DAC countries, including multilateral organizations (\$ billions)

\begin{tabular}{llrrrrr}
\hline \hline & 1969 & 1974 & 1979 & 1984 & 1989 & 1994 \\
Europe & 0.3 & 0.1 & 0.8 & 0.4 & 0.4 & 2.2 \\
Africa, North of Sahara & 0.3 & 1.5 & 2.4 & 2.5 & 2.5 & 3.9 \\
Africa, South of Sahara & 1.3 & 2.7 & 6.7 & 8.2 & 14.8 & 18.9 \\
North \& Central America & 0.3 & 0.6 & 1.6 & 2.3 & 2.6 & 3.2 \\
South America & 0.5 & 0.7 & 0.9 & 1.1 & 1.8 & 2.5 \\
Middle East & 0.2 & 1.5 & 5.1 & 3.5 & 2.3 & 4.4 \\
South \& Central Asia & 1.4 & 2.8 & 4.1 & 4.6 & 6.3 & 7.9 \\
Far East Asia & 1.5 & 2.3 & 2.2 & 2.9 & 6.3 & 8.4 \\
Oceania & 0.2 & 0.5 & 0.9 & 1.0 & 1.4 & 1.8 \\
LDCs unspecified & 0.4 & 1.3 & 4.8 & 4.8 & 7.7 & 7.8 \\
Total & 6.3 & 14.1 & 29.5 & 31.1 & 46.1 & 60.9 \\
\hline \hline
\end{tabular}

Source: OECD, Development Assistance Committee, Development Co-operation, various issues.

the world, that is the objective is to increase the recipients' welfare. Moreover, donors and recipients can be found all over the world.

Finally, we want to point out that international transfers are also made within institutionalized frameworks other than the United Nations, the World Bank or the International Monetary Fund. The European Union (EU), for example, levies contributions from its fifteen members which, after the deduction of operating expenses, are redistributed among the members (Grilli and Riess 1992). This redistribution in essence leads to international unilateral transfers and is mainly based on (i) agricultural policy and (ii) structural funds to assist poorer regions. Table 1.10 gives an overview of the share of the total funds the member countries contribute to and receive from the EU. Germany and the Netherlands are (relatively) the largest net contributors, both paying about twice as much as they receive. Greece, Spain, Ireland and Portugal are (relatively) the largest net recipients, each receiving more than twice as much as they contribute.

For the relatively largest net recipients, the transfers from the EU can be substantial, certainly if we compare their relative size with the evaluation of the historical transfers in section 1.6 (see the last column of table 1.7). Ireland, for example, contributed on average 1.5 percent of its GNP annually to the EU in the period 1990-6, while receiving on average 7.1 percent of its GNP annually from the EU in the same period. Over these seven years net receipts were therefore equal to $7.1-1.5=5.6$ 